Pamiętnik Literacki 2021, 2, s. 143-151

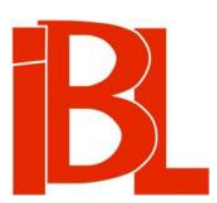

\title{
Jana Potockiego kłopoty z pocztą
}

\author{
Janusz Ryba
}


Pamiętnik Literacki CXII, 2021, z. 2, PL ISSN 0031-0514

DOI: $10.18318 / \mathrm{pl} .2021 .2 .10$

JANUSZ RYBA Uniwersytet Śląski, Katowice

JANA POTOCKIEGO KŁOPOTY Z POCZTĄ

Zapowiadająca się świetnie kariera Jana Potockiego (autora genialnego Rękopisu znalezionego $w$ Saragossie, uczonego i nieprzeciętnego erudyty) w carskiej (petersburskiej) administracji, po odejściu Adama Jerzego Czartoryskiego ze stanowiska ministra spraw zagranicznych Rosji (w r. 1806), uległa zahamowaniu. Potocki miał świadomość, że sprawy przybrały dla niego zły obrót. We wrześniu 1807 zrezygnował ze stanowiska naczelnego redaktora „Journal du Nord”, prestiżowej (propagandowej) gazety rządowej (carskiej), którą współtworzył. W listopadzie 1807 poprosił o 6-miesięczny urlop i otrzymawszy go, wyjechał na Ukrainę - by odwiedzić najbliższych. U schyłku urlopu udało mu się go przedłużyć o kolejne 6 miesięcy. Kiedy urlop się skończył, powrócił do Petersburga. Po krótkotrwałym pobycie w stolicy imperium poprosił o trzeci z kolei - również 6-miesięczny, który decyzją władz stał się bezterminowy. Ponownie wyruszył na Ukrainę ${ }^{1}$. Tutaj urodził się; tutaj miał majątek; stąd pochodziła druga jego żona - Konstancja, córka Stanisława Szczęsnego Potockiego, targowiczanina, właściciela luksusowego Tulczyna, posiadacza ogromnych dóbr, i Józefiny z Mniszchów.

Kiedy zjawił się na ukraińskiej ziemi - w wyniku przyznawanych mu kolejno urlopów; $\mathrm{z}$ myślą o osiedleniu się tutaj - zdecydował się na rozwód z żoną (co nie ochłodziło jego stosunków z Potockimi z Tulczyna) ${ }^{2}$. Było to w styczniu 1809. Do tych terenów ciągnęło go także dlatego, że mieszkało tutaj troje jego dzieci, które narodziły się ze związku z Konstancją: Andrzej Bernard oraz dwie córki - Irena i Teresa, z czasem powód coraz bardziej zażartej rywalizacji z byłą żoną o dominujący wpływ na ich losy.

W Uładówce Turek Ibrahim, zarządca dóbr, wybudował Potockiemu niezbyt duży dwór w stylu orientalnym. W tym okresie przebywał jednak najczęściej w pałacu

1 Zob. R. Radrizzani, Chronologie. W: J. Potocki, Manuscrit trouvé à Saragosse. Éd. R. Radrizzani. Wyd. 2. Paris 1992, s. 681-689. - F. Ross et, D. Triair e: Jan Potocki. Biografia. Przeł. A. W a silew ska. Warszawa 2006, rozdz. Carski stuga (1805-1808) i Uczona samotność (1808-1815); Chronologie. W: J. P o t o c k i, Manuscrit trouvé à Saragosse (version de 1810). Paris 2008, s. 833-846.

2 Ród Potockich dzielił się na dwie linie: prymasowską i hetmańską, oraz wiele gałęzi, m.in. gałąź tulczyńską - do której należała Konstancja. Zob. T. Zi e li ń s k a, Poczet polskich rodów arystokratycznych. Warszawa 1997, s. 253-286. 
tulczyńskim, który stał przed nim - znamienitym gościem - zawsze otworem. W Tulczynie, dużo czasu poświęcał, z jednej strony, dzieciom, z drugiej - studiom naukowym.

Tulczyn stopniowo tracił jego sympatię, zwłaszcza traciła ją królująca w tamtejszym towarzystwie, sprawująca pieczę nad rezydencją, Zofia Greczynka, wdowa po właścicielu, Stanisławie Szczęsnym Potockim. W jednym z listów do brata Seweryna krajczyc użył nawet sformułowania „podły Tulczyn” (,chien de vilain Tulczyn") ${ }^{3}$. Początkowo robił tylko wypady do Uładówki, później bywał tutaj częściej, by wreszcie przeprowadzić się tam na stałe. Do zerwania $z$ tulczyńskim société doszło już w bardzo późnej fazie jego życia.

Większość tych terenów (Peczara, Daszów, Humań, Tulczyn, Niemirów etc.) należała do Szczęsnego Potockiego, a w czasach kiedy pojawił się tam Jan Potocki do spadkobierców Szczęsnego, który zmarł w 1805 roku. Było ich wielu. $Z$ drugiego małżeństwa (z Józefiną z Mniszchów) Szczęsny miał jedenaścioro dzieci; z trzecią żona, Zofią Greczynką - pięcioro (nie licząc zmarłych we wczesnym dzieciństwie). Wszyscy oni (włączając w to wdowę) uczestniczyli w wielkiej zbiorowej kłótni o wielomilionowy spadek po Szczęsnym. Nieustannie podważano przyjęte już z wielkim trudem ustalenia. Każdy ze spadkobierców chciał otrzymać jak najwięcej. Sprawy kontrowersyjne, za zgoda zainteresowanych, wielokrotnie rozpatrywano w Petersburgu. Jerzy Łojek pisze: „Spory rodziny Potockich raz jeszcze wróciły do petersburskiego senatu [...]"4.

Prawdopodobnie w Tulczynie krajczyc poznał Marię z Rzewuskich Potocką, córkę Seweryna Rzewuskiego, targowiczanina, i Konstancji z Lubomirskich. Młoda, piękna, inteligentna, o uroku nieskazitelności moralnej ${ }^{5}$ - przypadła mu do gustu. Znajomość z Marią okazała się dla Potockiego niewątpliwie szczęśliwym trafem. Wniosła w dojrzałą fazę jego życia świeżość, młodość, idealizm. Dzięki wymienionym walorom stała się pożądanym interlokutorem - i epistolarnym, i salonowym. Była siostrzenica Potockiego. Pierwsza jego żona (Julia) - to siostra jej matki. Maria wyszła za Jarosława Potockiego (Gerochon lub Jerochon z listów), syna Stanisława Szczęsnego i Józefiny z Mniszchów, w przyszłości marszałka dworu cesarskiego i generał-majora wojsk rosyjskich. Wydała się za niego tuż przed nawiązaniem korespondencji $z$ wujem. Jan Potocki skoligacił się także $z$ Jarosławem - siostra Jarosława (wspomniana Konstancja) została jego drugą żoną, z którą, przypomnijmy, rozszedł się w styczniu 1809.

3 J. Potocki, Listy do brata Seweryna. Oprac. D. Triaire. W: F. Rosset, D. Triaire, $Z$ Warszawy do Saragossy. Jan Potocki i jego dzieło. Przeł. A. W a sil e w s k a. Warszawa 2005, s. 59 (list z Irkucka, z 24 IX 1805). W wersji oryginalnej (francuskiej) list ten znajdziemy w: J. P ot o c ki, OEuvres. Éd. F. Ro s s et, D. Tria ir e. T. 5: Correspondance. Varia. Louvain-Paris-Dudley 2006, s. 119.

$4 \quad$ J. Łoj e k, Dzieje pięknej Bitynki. Warszawa 1982, s. 308.

5 Kolportowane w towarzystwie opinie o Marii Potockiej były bardzo przychylne. Tak więc G. z G ü ntherów Puzynina pisała o niej: „Małżonka jego [tj. Jarosława], Rzewuska $z$ domu, rozumna i cnotliwa kobieta [...]" (W Wilnie i dworach litewskich 1815-1843. Wyd. A. Czartkowski, H. M o ś c i c ki. Wilno 1928. Wyd. fotooffsetowe: Kraków 1990, s. 323). W podobnym tonie wypowiadał się Z. Krasiński w liście do ojca: „Byłem u pani Potockiej z listem jej męża. Jest to kobieta rzadka, pełna uczuć wzniosłych i serdecznych [...]" (Listy do ojca. Oprac., wstęp S. Pig oń. Warszawa 1963, s. 291). 
Maria w czasach kontaktów listowych z Potockim mieszkała w Daszowie, którego, wbrew temu, co pisze Dominique Triaire, znany francuski badacz, nie była właścicielką ${ }^{6}$. Daszów należał do latyfundium Szczęsnego Potockiego, a po jego smierci, w wyniku wspomnianych rodzinnych podziałów pozostałej po nim schedy, stał się własnością Włodzimierza, brata męża Marii, któremu z kolei w ramach tychże podziałów przypadły posiadłości Mohylna i Sitkowce ${ }^{7}$.

Kontakt listowy Potockiego i siostrzenicy obejmuje lata 1809-1812. Z tego okresu pochodza jego listy, wyłącznie jego; obecnie znajdują się w posiadaniu Biblioteki Polskiej Akademii Nauk w Krakowie. Jest ich 23; zredagowane zostały po francusku. O tym, o czym pisała Maria, możemy dowiedzieć się pośrednio - z wujowskich listów.

Większość z nich zbudowana jest przeważnie z kilku „listów wewnętrznych” z których każdy opatrzono informacja, w jakim dniu tygodnia został napisany, bądź datą dzienną. W rezultacie tych zabiegów - mnożenia w obrębie przekazu listowego wewnętrznych struktur epistolarnych - przekaz przybierał postać „wielopiętrowej”, „szkatułkowej” konstrukcji. Tak więc list w kolejności chronologicznej trzeci zawiera dwa takie „listy wewnętrzne”: inicjalny - z 30 V 1809; drugi - z 31 V. List w kolejności piąty rozpoczyna się „listem” z niedzieli (22 X 1809); kolejny został napisany w poniedziałek $(23 \mathrm{X})$; ostatni pochodzi $\mathrm{z}$ soboty $(28 \mathrm{X})$. „List” inicjalny rozpoczyna się zwrotem do adresatki („Moja Droga Siostrzenico”); kolejny jest tego zwrotu pozbawiony; w ostatnim pojawia się ponownie, nieco zmodyfikowany („Moja Droga Mario”); tutaj też mamy słowo zamykające cały list - „Żegnaj”. W tych „wielopiętrowych" konstrukcjach epistolarnych formuła pożegnania występuje zawsze w ostatnim „liście wewnętrznym” (Potocki panował więc nad tym swoistym „labiryntem”) .

„Listy wewnętrzne”, współtworzące te epistolarne całości, mówią o różnych sprawach, otwierają nowe kręgi tematyczne czy problemowe i nie mają nic wspólnego $z$ poetyka postscriptum. Doprowadziło to do sytuacji, że realnie listów jest znacznie więcej niż wynikałoby $\mathrm{z}$ formalnego punktu widzenia (patrząc $\mathrm{z}$ takiego punktu widzenia, do Marii zostały wysłane, przypomnijmy, 23 listy).

Ludzie oświecenia pisali nieprawdopodobnie dużo listów - zwłaszcza przedstawiciele świata arystokratycznego chętnie oddawali się epistolografii; dla nich było to ulubione zajęcie - jednocześnie pasja i kulturowy nawyk. Efektownie napisane lettres ludziom ze społecznego establishmentu przynosiły sławę; tym, którzy do niego nie należeli - wydatnie pomagały w karierze. Oświeceniowi epistolomani pisali po kilkanaście, nawet po kilkadziesiąt tysięcy listów (m.in. Wolter, Thomas Jefferson, Ludovico Antonio Muratori). Formacja ta wydała również szereg wybitnych epistolografów (m.in. Marie du Deffand, Julie de Lespinasse, Philip Dormer Chesterfield czy Stanisław August Poniatowski) ${ }^{8}$. $Z$ tej oświeceniowej pasji do pisania

6 D. Triaire taką informacje podał w przypisie 4 do wydanych przez siebie $\mathrm{z}$ rękopisu listów Potockiego do Marii (J. Poto cki, Listy do siostrzenicy Marii. W: Ro s s et, Tria ir e, $Z$ Warszawy do Saragossy, s. 95).

7 Zob. Zielińs ka, op. cit., s. 270.

8 O epistolografii zob. m.in.: G. La n s o n, P. Tu ffr a u, Historia literatury francuskiej $w$ zarysie. Przeł. W. Bi eńkowska. Warszawa 1963, s. 394, 403-405. - P. Hazard, Myśl europejska $w$ XVIII wieku. Od Monteskiusza do Lessinga. Przeł. H. Suwała. Wstęp S. Pietraszko. 
listów skorzystała ówczesna poczta - zwielokrotniając zyski („W rezultacie król [Stanisław August] miał dochody i poczmistrzom nieźle się wiodło”9). $Z$ racji krociowych dochodów przywilej pocztowy stał się w tych czasach przedmiotem intensywnych zabiegów i zaciekłej rywalizacji.

Wywyższenie i rozkwit epistolografii w czasach oświecenia miały kilka przyczyn. Jedna $z$ nich - to charakterystyczna dla oświeceniowej kultury dominacja żywiołu rozmowy, który przeniknął do epistolografii i zawłaszczył ją. List dla oświeconych stał się przedłużeniem aktu rozmowy - jak to ujął Franciszek Bieńkowski w artykule Myśli o darach mówienia (zmieszczonym w „Zabawach Przyjemnych i Pożytecznych”): „Nie trzeba tak pisać, jak się mówi, prócz listów, które są mową oddalonych od siebie" 10 .

Najwykwintniejszą i najszlachetniejszą formę ekspresji słownej - konwersację uprawiano w salonach. Nawykli do salonowej conversation światowcy, często, z powodu nieobecności przyjaciół (chwilowej lub długotrwałej, nierzadko wynikającej z ich skłonności do wojaży), aby rozproszyć wywołane tą sytuacją smutek i znudzenie, zaczynali z nimi „rozmawiać” listownie. I właśnie tej modnej i bardzo popularnej wówczas konwersacji epistolarnej (na odległość), żyjąc w oddalonych od siebie miejscowościach, z pasją zaczęli się oddawać Jan Potocki i jego siostrzenica.

Taki typ rozmowy niósł jednak pewne niebezpieczeństwo. Otóż nie wystarczyło napisać błyskotliwy komunikat, należało jeszcze ten komunikat dostarczyć adresatowi (interlokutorowi), który mógł znajdować się w odległości kilkudziesięciu kilometrów od jego nadawcy, a to wiązałoby się z pewnymi (nieraz nawet dosyć dużymi) kłopotami i utrudnieniami.

Dostarczaniem korespondencji na terenach, które zamieszkiwali Jan Potocki i jego krewni, zajmowała się już wówczas poczta rosyjska. Wcześniej - do drugiego rozbioru Rzeczypospolitej - trudniła się tym polska poczta (stanisławowska), uchodząca w Europie (po reformie przeprowadzonej przez ostatniego króla) za znakomita („Obcy, jak i swoi świadczyli jednozgodnie o doskonałości poczty [...] a uprzejmości poczmistrzów [...]"11).

Poczta rosyjska nie była już taka dobra; nie dorównywała polskiej poziomem organizacyjnym ani sprawnością pocztylionów i kurierów; postępowała dość nonszalancko: cechowała ja pewna nieobliczalność co do terminu dostarczania przesyłek. Zofia Greczynka, pisząc z Tulczyna do Szczęsnego Jerzego, pasierba (z którym przeżyła ognisty romans), przebywającego we Francji, skarżyła się: „To prawda, że poczta dochodzi do nas czasami bardzo opieszale, nawet gazety wcale nie przycho-

Warszawa 1972, s. 213. - M. Ch a r p en ti er, J. C h a r p en ti e r, Littérature. Textes et documents. Paris 1987, s. 166-171.

9 Encyklopedia staropolska. Oprac. A. Brückner. Materiał ilustracyjny K. Estreicher. T. 2. Warszawa 1990, k. 163 (wyd. fotooffsetowe).

10 Cyt. z: Ludzie oświecenia o języku i stylu. Oprac. Z. Florczak, M. R. Mayenowa. T. 1. Warszawa 1958, s. 45.

11 Encyklopedia staropolska, loc. cit. 
dza" ${ }^{12}$. Krytycznie oceniła funkcjonowanie imperatorskiej poczty także w liście do Nikołaja Nowosilcowa, swojego kochanka, wielkiego dygnitarza carskiego, który czuwał w Petersburgu nad jej sprawami majątkowymi (spadkowymi): „Osiem dni temu otrzymałam list twój [...]; długo był w drodze, chociaż utrzymują, że wysłano go przez sztafetę"13. Tak więc nawet carscy notable nie byli sprawnie i szybko obsługiwani.

Większość ziem należących do imperium charakteryzowała się kiepską infrastrukturą drogową, która poważnie utrudniała pocztową komunikacje, dodatkowo obniżając standard usług. Zły stan dróg dotyczył też ziem ukraińskich; pogoda bywała tutaj dosyć kapryśna, co często czyniło je nieprzejezdnymi. Fatalne drogi i zmienna pogoda były (oczywiście) dokuczliwe nie tylko dla carskiej poczty. Utrudniały także jakikolwiek nieinstytucjonalny obieg przesyłek na tych terenach. $W$ listach do siostrzenicy Potocki kilkakrotnie sygnalizował ten uciążliwy dla Ukrainy problem; w jednym $\mathrm{z}$ nich donosił:

Moja Droga Mario, napisałaś uroczy list, na który jeszcze nie odpowiedziałem, ponieważ błoto, narastające między naszymi półkulami, wzniosło trwałe przeszkody. Osoby, które wyruszyły do Daszowa, musiały zawrócić, nie ujechawszy nawet pół mili. [wiosna 1809; s. 79] ${ }^{14}$

Bardzo rzadko krajczyc przywołuje pocztę; jeżeli pojawia się informacja na jej temat - to jest krytyczna: „Wczorajsza poczta nie przywiozła ani listów, ani gazet i nic już nie wiemy [...]” (22 IV 1811; s. 88).

Tak więc (raczej) nie można było polegać na usługach carskiej instytucji pocztowej. Potocki z siostrzenica (a także ludzie tam żyjący) dobrze o tym wiedzieli. Można było natomiast, taka istniała alternatywa, wziąc sprawy (pocztowe) w swoje ręce. Wymagało to, oczywiście, inwencji, przedsiębiorczości i zaradności, energii oraz wysiłku. Mimo tych niedogodności i kłopotów (nie zapominajmy także o złych drogach i często niesprzyjającej pogodzie) Maria Potocka i jej wuj (jak chyba również wielu tamtejszych mieszkańców) zdecydowali się na takie właśnie rozwiązanie: samodzielnie, we własnym zakresie organizować ekspedycję korespondencji. I ten kontekst „pocztowy” (wysyłanie przesyłek „prywatnie”), który nieustannie towarzyszył Potockiemu podczas pisania listów do Marii, przeniknął do nich, stając się jednym $\mathrm{z}$ istotniejszych wątków treściowych, które poruszały.

Liczne wzmianki dotyczą (między innymi) kategorii osób, które (z polecenia Potockiego) zawoziły listy do Marii. Otóż krajczyc często ekspediował przesyłki za pośrednictwem „umyślnych” (których funkcję pełnili ludzie $z$ jego dworu). W liście z 22 IV 1811 pisał: „Żegnaj, Moja Dobra Mario, chcę Ci wysłać umyślnego” (s. 89). W nieco późniejszym (z lata 1811) zanotował: „Posyłam Ci umyślnego, odpowiedz i podaj ostateczną date wyjazdu” (s. 90). W innym jeszcze - termin „umyślny” (,exprès”) zastapił „gońcem” („estafette”), pisząc: „Słyszałem, że pokój został zawarty, gdybym miał pewność, wysłałbym Ci gońca” (3 XI 1809; s. 83). Poprzestańmy na tych kilku przykładach.

Jeżeli chodzi o Marię - dostarczaniem wujowi korespondencji najczęściej zaj-

Cyt za: Łojek, op. cit., s. 281.

Cyt. jw., s. 278.

14 Daty listów i numery stronic odsyłają do: P o to c ki, Listy do siostrzenicy Marii. 
mował się koniuszy z jej dworu (kilkakrotnie pojawia się w listach). Jako „umyślny” nie tylko przyjeżdżał do krajczyca z przesyłką od siostrzenicy, także zabierał listy, które Potocki napisał do niej: „Twój koniuszy właśnie przybył, kończę więc list” (21 VII 1809; s. 80).

Obok „umyślnych” posłańców misję dostarczania przesyłek do siostrzenicy krajczyc zlecał Żydom (chyba częściej niż dworskim wysłannikom). Byli niewątpliwie mniej dyspozycyjni niż służba. W ówczesnej sytuacji stali się jednak (niemal) niezbędni. To właśnie dzięki żydowskim „listonoszom” Potocki mógł nieraz cieszyć się z możliwości szybkiego, sprawnego doręczenia przesyłki: „Moja Droga Mario, dostałem właśnie Twój list i cieszę się, że mam okazję przesłać odpowiedź przez Jankiela" (poczatek 1809; s. 78).

W liście z 22 X 1809 krajczyc sformułował opinię, że kiedy wszystkie sposoby doręczenia listu zawodzą, liczyć można (właśnie) na żydowskich „emisariuszy pocztowych":

Moja Droga Siostrzenico. Powierzyłem wczoraj list Cecolemu, a dzisiaj zaczynam następny. Mam nadzieję, że opatrzność znajdzie jakiś sposób, abyś go dostała, w razie potrzeby poślę Żyda. [s. 81]

Żydowski „emisariusz”, udający się w interesach do Daszowa, który zgadzał się zabrać (przy okazji) list do siostrzenicy, narzucał zazwyczaj dość luźny termin jego odebrania: w każdej chwili mógł przybyć po przesyłkę, dlatego Potocki był zmuszony napisać list, nie zwlekając - by powierzyć go doręczycielowi, kiedy tylko ten się pojawi. Donosił o tym Marii (w liście z kwietnia 1812): „Moja Dobra Mario, piszę do Ciebie, ponieważ w pierwszej dogodnej sytuacji Merkury Jankiel przyjdzie mnie powiadomić, że nadarza mu się okazja [...]" (s. 91).

Potocki obawiał się, że Jankiel może wycofać się z prowadzenia rozmaitych (drobnych) interesów z Marią i zaprzestać odwiedzać Daszów, a to utrudniłoby wymianę korespondencji $z$ siostrzenica. Nie doszło jednak do tego - list, w którym podzielił się z Marią tą obawa ( $\mathrm{z}$ kwietnia $1811 \mathrm{r}$.), był o rok wcześniejszy od tego, w którym poinformował, że Jankiel przyjdzie jednak odebrać przesyłkę dla Marii. Tak więc nadal zaspokajał on „kurierskie” potrzeby właściciela Uładówki.

Tę swoistą zależność Potockiego-,epistolografa” od żydowskich posłańców w jeszcze większym stopniu niż powyżej zacytowany ujawnia inny list $-\mathrm{z}$ wiosny 1811: „Żegnaj, Droga Mario, Żyd, który ma oddać Ci ten list, spieszy się z wyjazdem” (s. 85-86). Ponieważ żydowski doręczyciel spieszył się, Potocki był zmuszony wręczyć mu przesyłkę natychmiast - zakończył więc pisanie.

Czasem do ekspediowania przesyłek krajczyc wykorzystywał przedstawicieli rodziny - tak więc w funkcji doręczyciela dwukrotnie w listach pojawił się Andrzej Bernard, najstarszy syn Potockiego $z$ drugiego małżeństwa (w przyszłości kawaler Orderu Virtuti Militari). Kiedy w 1809 r. rozpoczęła się epistolarna konwersacja między krajczycem a Marią Potocką, Andrichon (tak najczęściej był określany przez ojca) miał 9 lat. Potocki, znakomity podróżnik, wprowadził w ówczesne życie syna dużo ruchliwości. M.in. zabierał go ze sobą do Daszowa; nierzadko wysyłał go tam samego: wyłącznie pod opieką służących - bo Andrichon polubił ojcowską siostrzenicę. Kursując między Tulczynem a Daszowem, mógł doręczać przesyłki. Potocki informował siostrzenicę: „Moja dobra Mario, otrzymałem przez Andrichona Twój list” (kwiecień 1811; s. 87). 
W kwietniu 1812 ojciec wyekspediował Andrzeja Bernarda na trzy dni do Peczary, posiadłości tulczyńskich Potockich, w której znajdował się piękny pałacyk pomniejszona kopia rezydencji w Tulczynie. Z przybyłym do Peczary Andrichonem miała spotkać się Maria i wręczyć mu przesyłkę dla ojca. Tak zostało to zaplanowane. Potocki pisał do niej: „André spędzi dwie noce w Peczarze. Daj mu list dla mnie i powiedz [...], jakie masz plany [...]” (15 IV 1812; s. 92).

To oczywiste, że André nie tylko przywoził (na prośbę ojca) listy od Marii, także, jadąc do niej, zabierał przesyłki dla ulubionej ojcowskiej siostrzenicy.

Omawiane listy raz tylko informują o rozczarowaniu autora - związanym $\mathrm{z}$ ich ekspedycją do Daszowa: „Skreśliłem tych parę słów, mając nadzieję, że oddam je komuś, kto się jednak nie pojawił. Wysyłam Ci je teraz z najlepszymi życzeniami noworocznymi. Żegnaj, Droga Mario" (początek 1811; s. 85). Nie wiemy, kim był ten, który miał „pojawić się”, by odebrać przesyłkę przeznaczoną dla Marii, i nie zjawił się. Potocki był dyskretny - nie wymienił jego nazwiska; salonowej grzeczności (politesse) obce były takie „donosicielstwo” i niedyskrecja; taktownie nie skomentował tego zachowania. W eleganckim stonowaniu emocji i zbagatelizowaniu incydentu ujawniła się jego perfekcyjna znajomość zasad, które określały postawę światowca. Wszystko jednak skończyło się dobrze: dzięki przedsiębiorczości, ale też dużemu doświadczeniu w tego typu działaniach krajczyc dość szybko znalazł kogoś, kto zawiózł do Daszowa ów list - ważny dla adresatki, bo z życzeniami noworocznymi od ukochanego wuja.

Wydawać by się mogło, że podczas pobytu w Berdyczowie, odległym od Tulczyna o 167 kilometrów, pozbawiony swojej prywatnej „infrastruktury pocztowej” (,umyślni”, żydowscy posłańcy, znajomi, rodzina), Potocki zdecyduje się skorzystać $z$ rosyjskiej poczty, by przesłać list na ręce Marii. Zrezygnował jednak z takiej możliwości. Sięgnął natomiast po wypróbowaną metodę: szukał i znalazł kogoś, kto jechał w jego rodzinne strony - w kierunku Daszowa - i zgodził się zabrać przesyłkę; to dawało nadzieję na pewne i w czasie niewattpliwie krótszym, niż zajęłoby to imperatorskiej poczcie, jej doręczenie. Potocki tak skomentował w epistolarnym przekazie (z 3 XI 1809) tę berdyczowską sytuację: „Opatrzność wyraźnie czuwa nad moją korespondencją z Daszowem, dostarczając mi zawsze okazji do wysłania listów. Wysyłam list niniejszy. [...] Żegnaj, Droga Mario” (s. 83).

Można tutaj dostrzec pewien dyskretny entuzjazm, że tak nieoczekiwanie udało mu się znaleźć doręczyciela przesyłki.

Dosyć długo jednak poszukiwał tego „emisariusza”, zanim znalazł go; musiał też czekać, aż ten, załatwiwszy swoje sprawy, zabierze list i ruszy w drogę. Świadczy o tym duża liczba „wewnętrznych listów”, tworzacych przygotowaną do wyekspediowania listowa przesyłkę: czekając, do inicjalnej notatki, swoim zwyczajem, w kolejnych dniach dopisywał kolejne „listy” - dopisał w piątek, w sobotę; nie dopisał w niedziele, poniedziałek i wtorek; ostatni listowy przekaz w tej „epistolarnej całości” zamieścił, według adnotacji, dopiero w środę. Gdyby „emisariusz” szybciej zdecydował się na wyjazd, nie byłoby zapewne owych dodatkowych listowych dopisków, redagowanych podczas kolejnych dni wyczekiwania. Stąd niewątpliwie (w znacznym stopniu) wzięła się owa, sygnalizowana już wcześniej, złożoność struktury („wielopiętrowość) epistolarnych przesyłek dla Marii.

Z Berdyczowa krajczyc udał się do Petersburga, stolicy imperium. Musiał po- 
konać trasę około 1300 kilometrów. Zapewne skorzystał, ciagle jeszcze grand seigneur (chociaż w fazie schyłkowej), $z$ wygodnego powozu; z kilku powozów - bo zabrał służbę. $Z$ carskiej stolicy wysłał do Marii dwa listy: czy czekał, aż szczęśliwy traf zetknie go $\mathrm{z}$ osobą, która, wracając w jego rodzinne strony, zgodzi się zabrać list do Daszowa, czy też, tym razem, zdał się na łaskę imperialnej poczty - tego nie wiemy.

$N b$. prawdopodobieństwo, że ktoś z Petersburga pojedzie na Ukrainę w czasie, kiedy Potocki przebywał w carskiej stolicy, i zabierze list do Marii, nie było takie małe. Przyciagał nieustannie luksusowy Tulczyn - przyjeżdżali tutaj znani Europejczycy, zwłaszcza francuscy emigranci, by zweryfikować to, co usłyszeli w Petersburgu o przepychu tej rezydencji ${ }^{15}$. Petersburska arystokracja i generalicja zajeżdżała do tulczyńskiego pałacu $z$ nadzieją na ożenek z którąs z licznych panien Potockich, otrzymujących w posagu $z$ reguły po milionie złotych. Do Tulczyna powracać mogli również młodzi przedstawiciele rodziny Potockich, którzy dość często i licznie zjawiali się w Petersburgu (co już sygnalizowano), by w siedzibie imperialnej władzy szukać poparcia dla swoich majątkowych pretensji i aspiracji - w toczącym się nieustannie sporze rodzinnym o spadek po Szczęsnym Potockim. Mając na uwadze przychylność tulczyńskiej rezydencji wobec znamienitych i głośnych gości (zwłaszcza $z$ imperatorskiego Petersburga), Potocki pisał do Marii z ironią (w liście z 10 V 1811): „Wiesz, że w Tulczynie zawsze się kogoś oczekuje” (s. 90).

Krajczyc starał się, by wymiana listów $z$ siostrzenicą miała charakter regularny (to warunek konwersacji). „Chciałbym, żeby nasza korespondencja nabrała bardziej regularnego rytmu" - wyznał w liście z 16 XI 1810 (s. 84). Śledząc daty wysyłanych do Daszowa przesyłek (Maria odpowiedziała zapewne na każdą z nich - czego sygnały odnajdujemy w licznych wypowiedziach Potockiego), można stwierdzić, że udało się to osiagnać - pod warunkiem jednak, że w tej ocenie nie uwzględnimy epizodu berdyczowsko-petersburskiego, który wyraźnie tę regularność zakłócił. Eskapada berdyczowsko-petersburska trwała ponad 12 miesięcy, a więc długo. W tym okresie krajczyc wyekspediował do siostrzenicy zaledwie 3 listy. Po powrocie z Petersburga na ukraińską prowincję, wolny od obowiązków służbowych, nie angażując się zbytnio w tutejsze życie towarzyskie, mógł ponownie skoncentrować się na epistolarnej aktywności. Napisane listy, jak przed wyjazdem, w pełni zaczęły znów podlegać procedurom „prywatnej poczty” krajczyca (niepozbawionej ryzyka, ale efektywnej). Dzięki temu korespondencja $z$ siostrzenica wróciła szybko do poziomu stabilnej, choć kruchej regularności z czasów poprzedzających jego wyjazd do rosyjskiej metropolii (via Berdyczów).

Należy zaznaczyć, że częstotliwość tej korespondencji nie była zbyt duża. Nawet taką częstotliwość można jednak uznać za osiagnięcie, oceniając ją z perspektywy kłopotów, jakie oboje korespondujący mieli $z$ wzajemnym doręczaniem przesyłek (co krajczyc przedstawił tak efektownie w epistolarnej narracji).

Trudno byłoby znaleźć zbiór listów, który, jak ten, eksponowałby tak silnie „techniczny” aspekt ich dostarczania adresatowi. To fenomen. 


\section{Abstract \\ JANUSZ RYBA University of Silesia, Katowice \\ ORCID: 0000-0003-0581-1067 \\ JAN POTOCKI'S PROBLEMS WITH THE POST}

Between the years 1809-1812 Jan Potocki exchanged letters with his niece Maria of the Rzewuski family who, at the time they started their correspondence, married Jarosław, the son of Józefina née Mniszech and Stanisław Szczęsny Potocki. Only Jan Potocki's letters survived: they are well written, brilliant, absorbed both with book knowledge and life wisdom. The author of the sketch concentrates, however, not on their stylistic and content matter issues, but on the way the letters were handed over.

The Ukrainian ways were in poor condition, and the tzarist post far from functional. Thus, letters reached their addressees as delayed, and often did not reach them at all. In view of that, Potocki and the recipient of his letters did not use it and employed servants, Jewish friends, and members of closest family to deliver the correspondence. The two letter writers constantly informed one another when and who would deliver letters. They told in confidence about temporary problems with a person to do the delivery, etc., and this issue is well developed in the epistles, giving it additional attractiveness. 